\title{
Loneliness in Infancy: Harry Harlow, John Bowlby and Issues of Separation
}

\author{
Frank C. P. van der Horst • René van der Veer
}

Published online: 13 August 2008

C The Author(s) 2008. This article is published with open access at Springerlink.com

\begin{abstract}
In this contribution, the authors give an overview of the different studies on the effect of separation and deprivation that drew the attention of many in the 1940s and 1950s. Both Harlow and Bowlby were exposed to and influenced by these different studies on the so called 'hospitalization' effect. The work of Bakwin, Goldfarb, Spitz, and others is discussed and attention is drawn to films that were used to support new ideas on the effects of maternal deprivation.
\end{abstract}

Keywords Separation $\cdot$ Maternal deprivation $\cdot$ Hospitalization effect $\cdot$ History of psychology $\cdot$ Attachment theory $\cdot$ Harlow $\cdot$ Bowlby

From the 1930s through the 1950s clinical and experimental psychology were dominated by ideas from Freud's psychoanalytic theory and Watson's behaviorism. Although very different in their approach to the study of (human) behavior, psychoanalysts and behaviorists held common views on the nature of the bond between mother and infant. According to scientists from both disciplines the basis for this relationship was a secondary drive, i.e. the fact that the child valued and loved the mother was because she reduced his or her primary drive for food.

The central figure of this special issue, American animal psychologist Harry Harlow (1905-1981), in the 1950s shifted his focus from studies of learning in monkeys (e.g., Harlow and Bromer 1938; Harlow 1949) to a more developmental approach-or in Harlow's own words a transition "from learning to love" (cf. Harlow and Harlow 1986). Inspired by the work of René Spitz (1945, 1946, 1951; Spitz and Wolf 1946, 1949) on hospitalization, Harlow started his groundbreaking experiments on the effects of separation and deprivation in infant rhesus monkeys (e.g., Harlow 1958; Harlow and Zimmermann 1959). With his cloth and wire mother

F. C. P. van der Horst $(\bowtie) \cdot$ R. van der Veer Centre for Child and Family Studies, Leiden University, P.O. Box 9555, 2300RB Leiden, The Netherlands e-mail: fhorst@fsw.leidenuniv.nl 
experiments he refuted classical drive reduction theory and psychoanalytic and behaviorist views on the nature and development of the mother-child bond. In 1957, shortly after his shift to studies of affection, Harlow became acquainted with British psychiatrist John Bowlby (1907-1990), who himself had been interested in issues of separation from a clinical perspective since the late 1930s. Harlow (in Zazzo 1979, p. 63) saw a clear parallel in the way that "at approximately the same time, Bowlby disputed the traditional view that affection and mother-infant attachment is based on food".

The roots of Bowlby's interest in separation lie in his own early childhood and in clinical experiences when training as a psychoanalyst shortly before the Second World War (Van Dijken et al. 1998). Bowlby's interest in separation resulted in his now famous work for the World Health Organisation (WHO) on Maternal care and mental health (Bowlby 1951), in which he reviewed the existing literature on the subject of deprivation of maternal care. More importantly, his assignment set Bowlby on track to start looking for a new theoretical framework for the explanation of the nature of the mother-child relationship - a framework he eventually found in ethology (Van der Horst et al. 2007) — resulting in his attachment trilogy (Bowlby $1969 / 1982$, 1973, 1980). Unfortunately, many of the findings Bowlby reported in his WHO monograph were based on practical experience or resulted from studies that were methodologically inadequate. Although he presented some retrospective evidence of the fact that deprivation had negative effects on the development of young children, there was no sound empirical evidence to support his claims. For that reason, Bowlby eventually turned to Harlow's separation studies for an empirical validation of his ideas (see Van der Horst, LeRoy and Van der Veer, this issue). Another way of conveying the message to a more general public was the distribution of films on this subject (e.g., Spitz 1947; Robertson 1952).

In this introduction we will give an overview of the different studies on the effect of separation and deprivation that drew the attention of many in the 1940s and 1950s and to which both Harlow and Bowlby were exposed. We will pay special attention to studies on the 'hospitalization' effect and we will show how both Harlow and Bowlby were influenced by the work of Bakwin, Goldfarb, Spitz and the like. We will also take a closer look at films by Spitz and Robertson that supported these new ideas on the effects of maternal deprivation. In doing so, we will lay the groundwork for other contributions in this special issue, more specifically Harlow's posthumously published work on his choice for the (rhesus) monkey as a psychological subject, LeRoy's reminiscences of working with Harlow, Van der Horst et al.'s contribution on the cross-fertilization of Harlow's and Bowlby's ideas, and Suomi et al.'s account of Harry Harlow's role in the history of attachment theory.

\section{Studies on the 'Hospitalization Effect'}

From the early 1940s, studies started to appear concerning the ill-effects of hospitalization of children. One of the first to address the issue of hospitalization was psychiatrist Lawson Lowrey (1940). He observed "the development and integration of personality" (p. 576) of 28 children who were placed in foster homes and of which nine were described in detail. The children showed very high percentages of 
"hostile aggressiveness, temper tantrums, enuresis [bedwetting], speech defects, attention demanding behavior, shyness and sensitiveness, difficulties about food, stubbornness and negativism, selfishness, finger sucking and excessive crying" (p. 579). According to Lowrey "[t]he conclusion seems inescapable that infants reared in institutions undergo an isolation type of experience" and that children "should not be reared in institutions" (p. 585).

More influential though was the work of pediatrician Harry Bakwin (1942), who described the care of small children in New York's Bellevue Hospital. The high mortality rate in this hospital was first assigned to malnutrition and infection. To avoid cross infections "the open ward (...) ha[d] been replaced by small, cubicled rooms in which masked, hooded and scrubbed nurses and physicians move[d] about cautiously so as to not stir up bacteria" (Bakwin 1942, p. 31). Surprisingly enough to people involved at the time, these measures had no effect whatsoever on mortality and Bakwin noted that, despite their high caloric diets, children would only gain in weight after they had returned home. He presumed that the "psychologic neglect" (p. 32) they endured, the total lack of mothering, and the sterile environment in the wards were damaging the children. Following a change in hospital policy, nurses were encouraged to mother and cuddle the children, to pick them up and play with them, and parents were invited to visit. The results of this change in policy were dramatic: despite the increased possibility of infection, the mortality rate for infants under 1 year of age fell sharply from 30-35 per cent to less than 10 per cent. Bakwin's paper was noticed by experts all over the world, including Britain. The impact of Bakwin's paper in Britain was amplified by the editors of the British Medical Journal, who discussed and supported Bakwin's ideas, and stated that "in infancy the loneliness involved in separation may be not only undesirable but lethal" (Editorial 1942, p. 345). Amongst the unanimously positive reactions that were subsequently sent to the British Medical Journal, was a letter by Bowlby's psychoanalytic colleague Donald Winnicott, who added that "we cannot take mothers from infants without seriously increasing the psychological burdens which the next generation will have to bear" (Winnicott 1942, p. 465).

At the time Bakwin made his observations in the USA, psychiatrist Harry Edelston (1943) did a similar study on separation anxiety in young children in Britain. He gathered and discussed data of 42 clinical cases at the London Child Guidance Clinic. Most of these children had experienced repeated admissions to hospital without the parents being allowed to visit. He noted that the children seemed very anxious and showed disturbed behavior. According to Edelston, the "separation from home (i.e., from the mother) form[ed] the essentially traumatic element in the experience" (p. 14) and "the younger and more helpless the child the greater the separation anxiety" (p. 83). In all, "the determining factor seem[ed] to be the degree of rejection or insecurity felt by the child" (p. 85, original italics). Unfortunately, this study seems to have escaped the attention of experts owing to the outbreak of the war in Britain (cf. Edelston 1940).

In nine publications on the care of (Jewish) children in foster homes in New York, psychologist William Goldfarb (1943a, b, c, d, 1944, 1945a, b, 1947, 1949) compared the prevalence of "aggressive behavior disorders" (Goldfarb 1943a, p. 250) in foster children with experience in institutions in the first 3 years of life to the behavior of foster children without such experiences. Goldfarb hypothesized that 
in the 'institution group' these behavior disorders were more likely to be found than in the 'foster home group'. The conditions in the institutions were similar to those described by Bakwin:

The children (..) had (..) been cared for in an institution with (..) an outstanding programme of medical prevention. Babies (...) were each kept in their own little cubicles to prevent the spread of epidemic infection. Their only contacts with adults occurred during those few hurried moments when they were dressed, changed, or fed by the nurses. These nurses had neither training nor time and resources to offer love and attention to a large group of babies. (...) $[\mathrm{A}]$ lmost complete social isolation during th[e] first year of life, (...) and [an] only slight enrichment of experiences that followed in the next two years. (Goldfarb 1947, p. 456)

Goldfarb (1943b, p. 127) noted that the institutionalized children had "an exceedingly impoverished, meagre, undifferentiated personality with related deficiency in inhibition and control" and a "passivity or apathy of personality". In the explanation of his findings, Goldfarb laid special emphasis on three main features in the institutions: (1) absence of stimulation, (2) absence of psychological interaction and reciprocal relation with adults, and (3) absence of normal identifications. The sterile climate in which the children lived, apparently had major consequences for later social interaction and Goldfarb concluded that a healthy interaction between children and their caregivers was of the utmost importance.

Psychoanalytically oriented psychiatrist René Spitz had worked on the issue of sterile children's wards with Katherine Wolf in Austria, before he fled the European continent to New York with hope of joining Bakwin and Goldfarb in their work on deprivation (Blum 2002). Spitz's main interest was in the relationship between mother and child and he was the first to coin the terms of 'hospitalism' and 'anaclitic depression' in children. "The term hospitalism designates a vitiated condition of the body to long confinement in a hospital, or the morbid condition of the atmosphere of a hospital" (Spitz 1945, p. 53). In Spitz's psychoanalytic jargon, an anaclitic depression was a "psychiatric syndrome of a depressive nature (...) related to a loss of the love object, combined with a total inhibition of attempts at restitution through help of the body ego acting on anaclitic lines" (Spitz and Wolf 1946, p. 339). Spitz studied the effect of continuous institutional care of infants under 1 year of age by comparing children in a nursery to children in a foundling home-as did Goldfarb before him. From his observations, Spitz concluded that (1) affective interchange is necessary for a healthy physical and behavioral development of infants; (2) this interaction is provided by reciprocity between mother (or mother substitute) and child; and (3) deprivation of this reciprocity is dangerous for the development of the personality of the child. Of the studies on hospitalization discussed here, Spitz's work on the effects of hospitalization was the most influential if we go by the number of citations, but it also came under heavy criticism. ${ }^{1}$

\footnotetext{
${ }^{1}$ Spitz (1945) paper alone has more citations than the other studies discussed here combined (Lowrey 1940; Bakwin 1942; Edelston 1943; Goldfarb 1943a, b, c, d, 1944, 1945a, b, 1947, 1949).
} 
Spitz was attacked by psychologist Samuel Pinneau (1955a, b; cf. Karen 1994; Spitz 1955), who essentially pointed his arrows at four different aspects of Spitz's studies: (1) Spitz's refusal to identify the dates and locations of his observations (cf. Anonymous 1952); (2) the inconsistency of the alleged number of children involved in the observations, which suggested a cross-sectional approach instead of the longitudinal study that Spitz presented; (3) Spitz's failure to account for the different cultural and racial background and socioeconomic status of the groups that were compared; and (4) the doubtful validity of the developmental scale, which jeopardized the interpretation of the test data. Despite this severe criticism, Spitz's work would be highly influential for for several decades. These studies about deprivation were noticed by many researchers and they led to an independent but simultaneous influence on both Harlow and Bowlby, to which we will now turn.

\section{Influence on Bowlby: Traveling Around Europe and the US for the WHO Report on Deprivation}

In 1949, Ronald Hargreaves, Bowlby's fomer colleague at the Tavistock Clinic and during the Second World War, by now Chief of the Mental Health Section at the WHO in Geneva, asked him to do a report on mental health problems of homeless children (Van der Horst et al. 2007). Bowlby read extensively into the early work on deprivation while working on this report. Also, in the first half of 1950, he traveled through Europe and the USA and met with people working in the field of psychiatric care. During a 5 week stay in the USA in March and April, he visited both Spitz and Goldfarb. In a letter to his wife Ursula he discussed his schedule:

As a result of my days [sic] activities I've made a huge number of appointments. On the whole I've been lucky in finding people available. Tomorrow, I'm busy morning [and] afternoon [and] in the evening have dinner with the Goldfarbs. (...) Monday I'm busy all day [and] dine with Spitz. (...) This means I get off to a flying start [and] don't waste time at the beginning which I'm pleased about. (Bowlby in a letter to Ursula, March 10, 1950; AMWL: PP/BOW/B.1/12) $)^{2}$

After meeting with them both, Bowlby was particularly impressed by the work of Goldfarb and wrote about his discussions with him:

All goes exceedingly well here-to the point where time for letter writing is hard to come by. Saturday was busy [and] fruitful, especially coffee with Goldfarb [and] his wife. I [wi]ll be writing a full description of this to Noel [Hunnybun $]^{3}$ so will only tell you now that he is a most attractive young man of [thirty-five], American born [and] not the least Jewish ${ }^{4}$, he has been doing no research for [four] years but has now nearly completed his medical studies. He

\footnotetext{
${ }^{2}$ AMWL stands for Archives and Manuscripts, Wellcome Library for the History and Understanding of Medicine, 183 Euston Road, London NW1 2BE. The letters PP/BOW stand for Personal Papers Bowlby.

${ }^{3}$ Noel Hunnybun was Bowlby's secretary at the Tavistock Clinic

${ }^{4}$ Perhaps Bowlby expected someone with the name Goldfarb to be Jewish.
} 
dines with me tomorrow night [and] the possibility of him coming to the Tavi [stock Clinic] for a year will be discussed. That would be a great acquisition. (Bowlby in a letter to Ursula, March 13, 1950; AMWL: PP/BOW/B.1/12)

After his meetings with Goldfarb, Bowlby indeed reported to Noel Hunnybun about Goldfarb's work:

Goldfarb is the real bright spot here, though for the past four years he has been in 'retirement' studying medicine. He is a delightful young man of 35, modest, sensitive and intelligent. (...) His work is not widely known, but is highly regarded in discriminating quarters. Personally he seems to be liked and respected. His studies seem to have been carried out between 1940-1946 off his own bat, and in his spare time. (...) He has done nothing for the past four years, though he has a great deal of interesting material (...) still unpublished. I raised with him the possibility of his coming to the Tavi[stock Clinic] for 12 months (...) to write his stuff up into a coherent monograph. He was greatly attracted by the idea and is thinking it over seriously. October 1951 is the earliest he could make as he has to complete a medical internship. He wants to become a psychiatrist and is already training in psycho-analysis. Though it is impossible to judge his ultimate ceiling, there is no doubt about his quality. (Bowlby in a letter to Noel Hunnybun, March 19, 1950; AMWL: PP/BOW/B.1/12)

In a staff meeting on May 11, after Bowlby had returned to England, he would add that Goldfarb would "get a senior job there [at Columbia University] (...) because I think there is little doubt that he is pretty well the best chap they have got" (Travelogue given by Bowlby, May 11, 1950; AMWL: PP/BOW/F.1/1). Goldfarb's move to the Tavistock Clinic was never realized.

Bowlby's travels and research ultimately led to his monograph Maternal care and mental health (Bowlby 1951), in which he discussed the state of the art and most recent advances in studies on deprivation. He discussed the work of Bakwin, Goldfarb, and Spitz under the heading of 'direct' studies on evidence of effects of deprivation in which observations are made in institutions and in foster homes. Bowlby's own early study of 44 thieves (Bowlby 1944, 1946) and the work of Lowrey and Edelston were categorized as 'retrospective' and 'follow-up' studies. These studies "taken by themselves are more than suggestive, but when all the evidence is fitted together it is seen to be remarkably consistent", Bowlby (1952, p. 46) argued. And he concluded that:

the evidence is now such that it leaves no room for doubt regarding the general propositions - that the prolonged deprivation of the young child of maternal care may have grave and far-reaching effects on his character and so on the whole of his future life. (Bowlby 1952, p. 46)

Much later, Bowlby would state that he had been greatly influenced by the work on deprivation, because it resulted in him focusing more on separation and institutionalization (Senn 1977). After the completion of his monograph, Bowlby's attention was drawn to ethology, a framework for the study of animal behavior that he would apply to human behavior and which he used as a theoretical basis for what later would be called 'attachment theory' (Van der Horst et al. 2007). 


\section{Influence on Harlow: Separation of Rhesus Monkeys}

In the early 1950s, Harry Harlow too was influenced by the work on deprivation, though in a more circumstantial way. At that time Harlow lost a group of monkeys because of tuberculosis, and so he decided to rebuild a colony of rhesus. Because of all the trouble getting sufficient monkeys - there was a big demand for rhesus monkeys, because of the development of the polio vaccine-Harlow decided to raise his own. He wanted to make sure they were in excellent health, so for reasons of hygiene and nutrition the baby monkeys were taken away from their mothers at birth, like human infants were at that time in hospitals (see also Harlow, this issue; cf. Helen A. LeRoy, personal communication, October 18, 2007). In fact, what Harlow was doing was setting up experiments which imitated the very hospital policies of hygienic isolation that Bakwin (1942) had been trying to undo in the 1940s. He thus unwittingly reproduced the circumstances that caused massive harm in human infants. It was only later that he realized that, although the baby monkeys were physically perfectly healthy, there behavior was very abnormal: they exhibited weird stereotypic behaviors, sucking their fingers and toes, and rocking back and forth. It might have been at this point that Harlow first took notice of the work of Spitz or at least noticed the analogy in behavior of human infants. According to Bowlby, there was a clear influence on Harlow by Spitz: "I think Harlow's work on rhesus monkeys was inspired by the work of Spitz" (in Zazzo 1979, p. 56; cf. Karen 1994; Rudnytsky 1997). Asked about the possible influence of his own work on Harlow's experiments, Bowlby, in an interview in 1977, again formulated Spitz's influence on Harlow as follows (in Smuts 1977):

I don't think [Harlow] had ever heard of anything we were doing [at the Tavistock Clinic]. [His] work had had a completely different inspiration. His work was, as I understand it, inspired by René Spitz's work. I may have said this before-I think one can't place too much emphasis on the importance of geography. You know, traditions which are immensely important in the States are of no consequence over here; traditions which are immensely important over here are of no consequence in the States. And it's fair to say as regards maternal deprivation and all that sort of thing, in this country it's associated with my name and in the States it's associated mostly with Spitz's name. And Harlow had been influenced by Spitz, and he was starting his monkey work in' $56 ;(. .$.$) he'd only been doing it for a year or so in' 57$.

Bowlby's assumption is supported by a Harlow letter to Spitz in which Harlow acknowledged Spitz's contributions to his work as early as 1963:

[L]et me assure you that you research has been a great inspiration and that your friendship has been a relationship of great meaning. I have vast faith in the research area that you have established and I will do my very best to forward it. (Harlow in a letter to Spitz dated January 22, 1963) ${ }^{5}$

\footnotetext{
${ }^{5}$ Harlow's correspondence resides with Helen A. LeRoy.
} 
So both Harlow and Bowlby were firmly aware of the possibly harmful effects of deprivation and isolation to young children articulated by Spitz and others. And if there had any doubts about these suppositions, there was other, even more cogent and probing material available: Spitz and his colleagues had films to support their new views and findings.

\section{A Picture Speaks a Thousand Words: Films to Support New Views}

Both in the UK and in the USA the field of psychology was stirred in a similar way. In the USA, Spitz shook the ground with his silent, black-and-white film Grief: A Peril in Infancy (Spitz 1947). Spitz filmed, amongst other children, a baby named Jane who within weeks after placement in a foundling home develops from a happy and approachable child into a distant and withdrawn one. Spitz himself described the cure for this child on one of the film's title cards: "Give mother back to baby". Jane is shown again, after her mother has returned after a 3 month separation, playing, clapping, and laughing. Reactions to Spitz's film were quite similar to the reactions James Robertson would later receive for his film: those of shock and disbelieve. Karen (1994, p. 25) described how after the film was shown to physicians and psychoanalysts at the New York Academy of Medicine, a "prominent New York analyst approached Spitz with tears in his eyes. 'How could you do this to us?' he said". Apparently, people were shocked by the sight of babies pining away from grief. It was something that they had not seen or been willing to see before.

In the UK, Robertson, social worker at the Tavistock Clinic, made a similar film called A Two-Year-Old Goes to Hospital (Robertson 1952)-black-and-white and silent, but with spoken commentary. In this film, an unusually controlled toddler named Laura leaves home for a period of 9 days to be admitted to hospital for the operation of an umbilical hernia. She changes from a "ravishing little girl" (Hinde, in Van der Horst et al. 2007) to a silent and unresponsive one. Robertson's film was first shown at the Section of Paediatrics of the Royal Society of Medicine on November 28, 1952, before a large audience of doctors and nurses. Both the editors of the British Medical Journal and The Lancet favorably discussed the meeting in their issues of December 6. The editors of the British Medical Journal (Editorial 1952a) agreed that "the 2-year-old girl depicted was unhappy and that possibly her unhappiness might have been prevented" (p. 1249). In The Lancet, the reactions by the audience were described in more detail (Editorial 1952b). According to the editors, at first the audience frankly refused to admit the child was distressed at all and those who accepted that Laura was distressed were reluctant to believe it might cause long-term or even permanent emotional disturbances. Robertson and Bowlby are said to have agreed that more research was needed but remained convinced that the child was upset, and that the isolation and lack of physical comfort in hospitals were positively bad (cf. Van der Horst and Van der Veer in press). Robertson's memory of the meeting is that "the film encountered much resistance" and that various speakers said hotly that he had filmed "an atypical child of atypical parents in an atypical ward" (Robertson and Robertson 1989, p. 44). Nonetheless, the evidence supporting the idea that the mother-child relationship was crucial to a healthy development was piling up. 


\section{Conclusion}

Slowly but surely people - in hospitals, foundling homes, nurseries - were beginning to see the effects of separation and deprivation on young children. The evidence gathered in studies by Lowrey, Bakwin, Edelston, Goldfarb and Spitz on the effects of early hospitalization - both in Britain and the USA — led people to believe that the physical and emotional separation from a familiar environment was detrimental to the child's well-being. Their views were supported by films such as those by Spitz and Robertson (for a full overview of films on children's hospitalization and maternal deprivation, see Mason 1967). Unfortunately, because of the retrospective nature of the reported findings, there could only be speculation about the mechanisms underlying them. It was up to others to lead the way to a theoretical and experimental validation of the consequences of maternal deprivation - and this is where Bowlby and Harlow entered the stage.

In this introduction to the special issue on Harry Harlow, we have described how both Harlow and Bowlby found inspiration to follow up on the findings from early studies on deprivation by Bakwin, Goldfarb, and Spitz. Elsewhere we have made abundantly clear how Bowlby used viewpoints of the new emerging European approach to animal behavior, ethology, to build his ideas on the mother child bond. From the 1950s Bowlby was in close personal and scientific contact with leading ethologist such as Niko Tinbergen, Konrad Lorenz, and especially Robert Hinde. Bowlby developed new explanatory hypotheses for what is now known as human attachment behavior and was able to reject dominant ideas prevailing in psychoanalysis and learning theory of the 1940s and 1950s (Van der Horst et al. 2007). In this special issue attention will be drawn to the empirical validation of the concept of 'attachment' and the 'nature of love' by Harlow. In all, by refuting classical drive reduction theories, the work of Harlow and Bowlby would have a huge impact on the field of child care and child development.

Open Access This article is distributed under the terms of the Creative Commons Attribution Noncommercial License which permits any noncommercial use, distribution, and reproduction in any medium, provided the original author(s) and source are credited.

\section{References}

Anonymous (1952). Milk. Time, 59(18), 51, May 5.

Bakwin, H. (1942). Loneliness in infants. American Journal of Diseases in Children, 63, 30-40.

Blum, D. (2002). Love at Goon Park. Wisconsin: Perseus.

Bowlby, J. (1944). Forty-four juvenile thieves: their characters and home-life. The International Journal for Psycho-Analysis, 25(19-53), 107-128.

Bowlby, J. (1946). Forty-four juvenile thieves: their characters and home-life. London: Ballière, Thindall and Cox.

Bowlby, J. (1951). Maternal care and mental health. Bulletin of the World Health Organization, 3, 355-534. Bowlby, J. (1952). Maternal care and mental health. Geneva: World Health Organization.

Edelston, H. (1940). Visiting in children's wards. Letter to the editor. The Lancet, 24, 391, February.

Edelston, H. (1943). Separation anxiety in young children: A study of hospital cases. Genetic Psychology Monographs, 28(1), 3-95. 
Editorial (1942). Loneliness in infancy. British Medical Journal, 2, 345, September 19.

Editorial (1952a). Young children in hospital. British Medical Journal, 1249-1250, December 6.

Editorial (1952b). The young child in hospital. The Lancet, 1122-1123, December 6.

Goldfarb, W. (1943a). Infant rearing and problem behaviour. American Journal of Orthopsychiatry, 13, $249-265$.

Goldfarb, W. (1943b). The effects of early institutional care on adolescent personality. Journal of Experimental Education, 12, 106-129.

Goldfarb, W. (1943c). The effects of early institutional care on adolescent personality (graphic Rorschach data). Child Development, 14, 213-223.

Goldfarb, W. (1943d). The effects of early institutional care on adolescent personality: Rorschach data. American Journal of Orthopsychiatry, 14, 441-447.

Goldfarb, W. (1944). Infant rearing as a factor in foster home replacement. American Journal of Orthopsychiatry, 14, 162-166.

Goldfarb, W. (1945a). Effects of psychological deprivation in infancy and subsequent adjustment. American Journal of Psychiatry, 102, 18-33.

Goldfarb, W. (1945b). Psychological privation in infancy and subsequent adjustment. American Journal of Orthopsychiatry, 15, 247-255.

Goldfarb, W. (1947). Variations in adolescent adjustment of institutionally-reared children. American Journal of Orthopsychiatry, 17, 449-457.

Goldfarb, W. (1949). Rorschach test differences between family-reared, institution-reared and schizophrenic children. American Journal of Orthopsychiarty, 19, 624-633.

Harlow, H. F. (1949). The formation of learning sets. Psychological Review, 56, 51-65.

Harlow, H. F. (1958). The nature of love. American Psychologist, 13, 673-685.

Harlow, H. F., \& Bromer, J. A. (1938). A test-apparatus for monkeys. Psychological Record, 2, 434-436.

Harlow, H. F., \& Harlow, C. M. (1986). From learning to love: The selected papers of H.F. Harlow. New York: Preager.

Harlow, H. F., \& Zimmermann, R. R. (1959). Affectional responses in the infant monkey. Science, 130, 421-432.

Karen, R. (1994). Becoming attached: unfolding the mystery of the infant-mother bond and its impact on later life. New York: Warner Books.

Lowrey, L. G. (1940). Personality distortion and early institutional care. American Journal of Orthopsychiatry, 10, 576-585.

Mason, E. A. (1967). Films on children's hospitalization and maternal deprivation. Community Mental Health Journal, 3(4), 420-423.

Pinneau, S. R. (1955a). The infantile disorders of hospitalism and anaclitic depression. Psychological bulletin, 52(5), 429-452.

Pinneau, S. R. (1955b). Reply to Dr. Spitz. Psychological bulletin, 52(5), 459-462.

Robertson, J. (1952). A two-year-old goes to hospital [Film]. London: Tavistock Child Development Research Unit.

Robertson, J., \& Robertson, J. (1989). Separation and the very young. London: Free Association Books.

Rudnytsky, P. L. (1997). The personal origins of attachment theory: an interview with Mary Salter Ainsworth. The Psychoanalytic Study of the Child, 52, 386-405.

Senn, M. J. E. (1977). Unpublished transcript of an interview with dr. John Bowlby in London, England.

Smuts, A. (1977). Interview with Dr. John Bowlby on 6th June and 23rd July, 1977; and additional written material sent by Dr. Bowlby in September and October, 1979. Unpublished (Archives Tavistock Joint Library).

Spitz, R. A. (1945). Hospitalism: An inquiry into the genesis of psychiatric conditions in early childhood. The Psychoanalytic Study of the Child, 1, 53-74.

Spitz, R. A. (1946). Hospitalism: A follow-up report on investigation described in volume I, 1945. The Psychoanalytic Study of the Child, 2, 113-117.

Spitz, R. A. (1947). Grief: A peril in infancy (Film). University of Akron Psychology Archives, Akron, Ohio (Available through the Penn State Audiovisual Services, University Park, PA).

Spitz, R. A. (1951). The psychogenic diseases in infancy: An attempt at their etiologic classification. The Psychoanalytic Study of the Child, 6, 255-275.

Spitz, R. A. (1955). Reply to Dr. Pinneau. Psychological Bulletin, 52(5), 453-459.

Spitz, R. A., \& Wolf, K. M. (1946). Anaclitic depression: an inquiry into the genesis of psychiatric conditions in early childhood, II. The Psychoanalytic Study of the Child, 2, 313-342.

Spitz, R. A., \& Wolf, K. M. (1949). Autoerotism: Some empirical findings and hypotheses on three of its manifestations in the first year of life. The Psychoanalytic Study of the Child, 3-4, 85-120. 
Van der Horst, F. C. P., \& Van der Veer, R. (in press). Changing attitudes towards the care of children in hospital: A new assessment of the influence of the work of Bowlby and Robertson in Britain, 19401970. Attachment \& Human Development.

Van der Horst, F. C. P., Van der Veer, R., \& Van IJzendoorn, M. H. (2007). John Bowlby and ethology: An annotated interview with Robert Hinde. Attachment and Human Development, 9(4), 321-335.

Van Dijken, K. S., Van der Veer, R., Van IJzendoorn, M. H., \& Kuipers, H. J. (1998). Bowlby before Bowlby: the sources of an intellectual departure in psychoanalysis and psychology. Journal of the History of the Behavioural Sciences, 34, 247-269.

Winnicott, D. W. (1942). Loneliness in infancy. British Medical Journal, 17, 465, October.

Zazzo, R. (1979). Le colloque sur l'attachement. [A colloquium on attachment]. Paris: Delachaux Niestlé Spes.

Frank C.P. van der Horst is a PhD student and Lecturer at the Centre for Child and Family Studies at Leiden University, The Netherlands. The work presented in this special issue is part of his doctoral thesis on the roots of Bowlby's attachment theory. The defence of this thesis, titled John Bowlby and ethology: a study of cross-fertilization, is scheduled for early 2009.

René van der Veer is Professor of History of Educational Thinking at Leiden University, The Netherlands. His research addresses the work of key educational thinkers such as Gal'perin, Janet, Piaget, Vygotsky, Werner, and Wallon. In a longer study the origin of the idea of the social mind was traced. He is on the Editorial Board of Integrative Psychological and Behavioral Sciences. 